\title{
Causes and consequences of the sinkhole at El Trébol of Quito, Ecuador - implications for economic damage and risk assessment
}

\author{
Theofilos Toulkeridis ${ }^{1}$, Fabián Rodríguez ${ }^{1}$, Nelson Arias Jiménez ${ }^{2}$, Débora Simón Baile ${ }^{1}$, Rodolfo Salazar Martínez ${ }^{1}$, \\ Aaron Addison $^{3}$, Dora Carreón Freyre ${ }^{4}$, Fernando Mato ${ }^{1}$, and Carmen Díaz Perez ${ }^{5}$ \\ ${ }^{1}$ Centro Geoespacial, Universidad de las Fuerzas Armadas ESPE, Sangolquí, Ecuador \\ ${ }^{2}$ Empresa Metropolitana de Alcantarillado y Agua Potable de Quito, Quito, Ecuador \\ ${ }^{3}$ Washington University St. Louis, Missouri, USA \\ ${ }^{4}$ Universidad Nacional Autonoma de México, Campus Querétaro, Querétaro, Mexico \\ ${ }^{5}$ Escuela Superior Politécnica de Chimborazo, Riobamba, Ecuador
}

Correspondence to: Theofilos Toulkeridis (ttoulkeridis@espe.edu.ec)

Received: 12 January 2016 - Published in Nat. Hazards Earth Syst. Sci. Discuss.: 5 February 2016

Revised: 9 August 2016 - Accepted: 10 August 2016 - Published: 2 September 2016

\begin{abstract}
The so-called El Trébol is a critical road interchange in Quito connecting the north and south regions of the city. In addition, it connects Quito with the highly populated Los Chillos Valley, one of the most traveled zones in the Ecuadorian capital. El Trébol was constructed in the late 1960s in order to resolve the traffic jams of the capital city and for that purpose the Machángara River was rerouted through an underground concrete box tunnel. In March 2008, the tunnel contained a high amount of discarded furniture that had been impacting the top portion of the tunnel, compromising the structural integrity. On 31 March 2008 after a heavy rainfall a sinkhole of great proportions formed in the Trébol traffic hub. In the first few minutes, the sinkhole reached an initial diameter of $30 \mathrm{~m}$. The collapse continued to grow in the following days until the final dimensions of $120 \mathrm{~m}$ in diameter and some $40 \mathrm{~m}$ of depth, revealing the Machángara River at the base of the sinkhole.

A state of emergency was declared. The cause of the sinkhole was a result of the lack of monitoring of the older subterranean infrastructure where trash had accumulated and damaged the concrete tunnel that channelized the Machángara River until it was worn away for a length of some $20 \mathrm{~m}$, leaving behind the sinkhole and the fear of recurrence in populated areas.

With the intent to understand the causes and consequences of this sinkhole event, rainfall data are shown together with hydrogeological characteristics and a view back to the recent history of sinkhole lineation or arrangement of the city of
\end{abstract}

Quito. The economic impact is also emphasized, where the direct costs of the damage and the reconstruction are presented and compared to indirect costs associated with this socio-natural disaster. These analyses suggest that the costs of indirect financial damage, like time loss or delay, and subsequent higher expenses for different types of vehicles, are equivalent to many times the costs of the reconstruction of El Trébol.

\section{Introduction}

The so-called El Trébol is the most important southern interconnector of the city to the Los Chillos Valley in the eastern end of Quito, one of the most traveled zones in the Ecuadorian capital (Fig. 1). It also serves as a connection of the southern to the northern side of the city, where an extremely high number of vehicles transit daily. El Trébol was constructed in the late 1960s in order to resolve the traffic jams of the capital city; for that purpose the Machángara River was rerouted through a concrete box tunnel. In March 2008, the tunnel contained a high amount of trash such as refrigerators, furniture, old parts of vehicles and even some motorbikes. These materials impacted the top portion of the tunnel, compromising the structural integrity.

Considering this context, on 31 March 2008, during a regular working day, heavy rainfall took place within an already extremely wet season, and around 14:00 LT, a sinkhole 


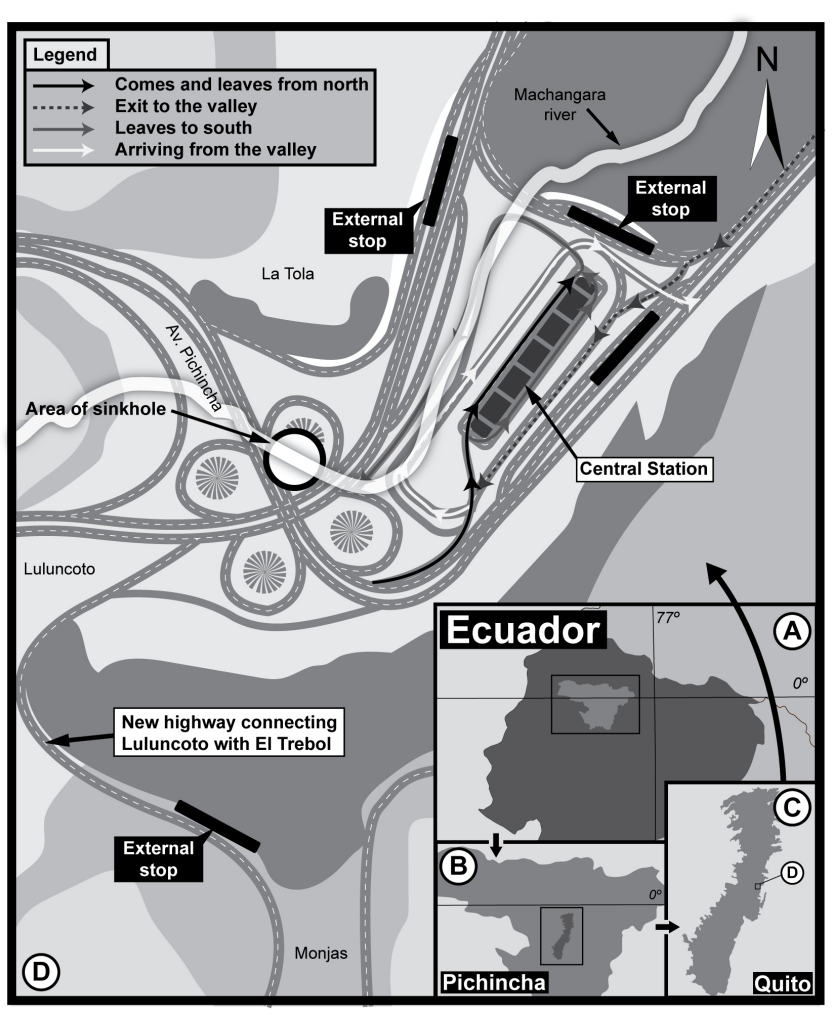

Figure 1. Overview of the setting of (a) Ecuador, (b) province of Pichincha, (c) city of Quito, and (d) El Trébol and surrounding infrastructure.

of great proportions was observed in the Trébol traffic hub (Fig. 2). In the first few minutes, the sinkhole started to generate in the form of a crater with a diameter of $30 \mathrm{~m}$ (Fig. 3). The collapse continued to grow in the following days until the final dimensions of this almost round sinkhole reached approximately $120 \mathrm{~m}$ in diameter and some $40 \mathrm{~m}$ of depth, revealing the base of the sinkhole, and the Machángara River (Fig. 4).

Although fortunately no person was harmed in any way, the generation of this sinkhole led to a traffic collapse and paralyzed the traffic of the south-central part of the city for the following weeks; therefore, a state of emergency was declared by the Municipality of Quito. Soon the cause of the sinkhole was recognized as a result of the lack of monitoring of the older subterranean infrastructure where trash had accumulated and compromised the concrete tunnel that channelized the Machángara River until it was worn away for a length of some $20 \mathrm{~m}$, leaving behind the sinkhole and the fear of recurrence in populated areas.

In order to understand the causes and consequences of this sinkhole event, rainfall data are shown together with hydrogeological characteristics and a view back to the recent history of sinkhole lineation or arrangement of the city of Quito. The economic impact is also emphasized, where the direct costs of the damage and the reconstruction are presented and

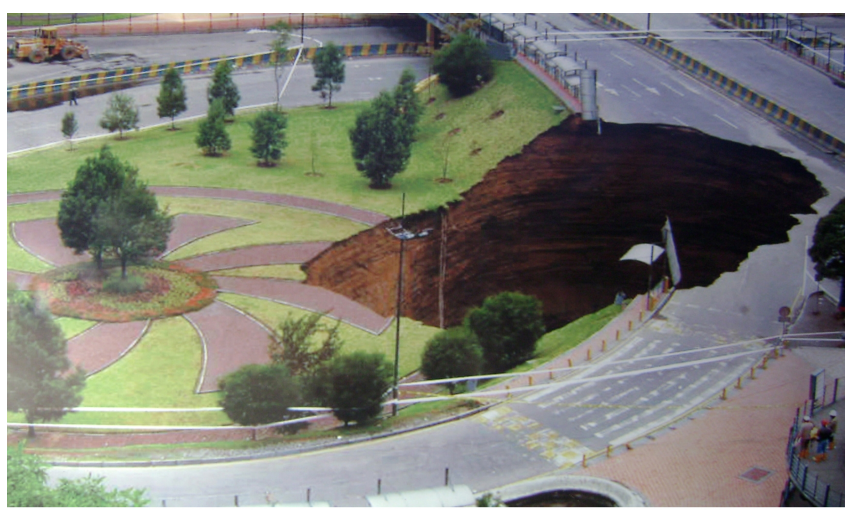

Figure 2. Initial stage of sinkhole at El Trébol.

compared to indirect costs associated with this socio-natural disaster. These analyses suggest that the indirect financial damage, like time loss or delay, and subsequent higher expenses for different types of vehicles, is many times the costs of the reconstruction of El Trébol.

Sinkholes can be of artificial, natural or combined origin as studied and observed in a variety of cities and regions (Beck, 1991, 2004; Aisong and Jianhua, 1994; Salvati and Sasowsky, 2002; Williams, 2003; Waltham et al., 2005). Sinkhole collapses in urban areas may be a man-made result of a forgotten and covered as well as outdated sewer system, of which its real magnitude appears to be a potential risk of unknown proportions. Such sinkholes may be absolutely devastating in the area where they appear and the appearance itself may occur without any warning. Prominent examples of sinkholes appeared in recent years in the United States like the Macungie sinkhole in 1986 (Dougherty and Perlow Jr., 1988), Daisetta sinkhole in 2008 (Paine et al., 2009), and in Guatemala City (Guatemala) in 2007 and 2010 (Hermosilla, 2012) and even in desert areas like in Kuwait (Shaqour, 1994). Man-induced sinkholes are associated with the increasing industrialization and urbanization of cities and the intense human economic activity in the investment of the corresponding hydrological systems (Reese et al., 1997; Gutiérrez et al., 2007, 2009; Brinkmann et al., 2008).

Based on considerably high economic damages caused by sinkholes in urban areas, the monitoring and detection with geophysical tools and geographic as well as historic data of sinkholes has recently been a major focus in city planning and hazard prevention (Orndorff and Lagueux, 2000; Lei et al., 2004; Gutiérrez-Santolalla et al., 2005; Gutierrez et al., 2008; Brinkmann et al., 2008; Bruno et al., 2008; Kaufmann and Romanov, 2009; Krawczyk et al., 2012; Margiotta et al., 2012).

In Quito (Ecuador), a variety of sinkholes occurred during the 20th century. However, it was not until 2008, when the great sinkhole within the area called El Trébol appeared, that the city population and city planners were reminded to re-evaluate the spatial distribution of past sinkholes in areas 


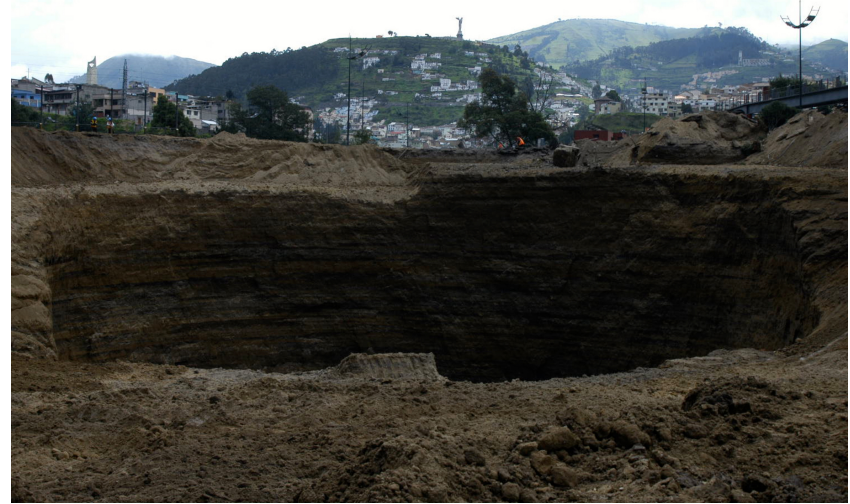

Figure 3. Panoramic view of the final stage of the sinkhole at El Trébol. On the background the Panecillo volcanic dome.

that might be vulnerable to such a hazard. It is of fundamental interest to society and authorities to identify their potential distribution in order to prevent the occurrence of further sinkholes and to assess the potential economic damage and loss of lives.

The aim of this study is of twofold as it focuses firstly on the causes of the sinkhole in 2008 and its direct and indirect economic damage. Secondly a historic reconstruction of past sinkholes and older sewer system has been carried out to help to indicate where future hazards may be triggered in order to monitor and prevent them by involving adequate and corrective mitigation measures in time. Therefore, this analysis intends to identify the causes of the collapse and afterwards to search for further areas with similar problems and vulnerabilities in order to prevent future disasters where people could be involved.

\section{Geological setting and geo-mechanical behavior of involved deposits}

In Ecuador two prominent cordilleras limit to the west and to the east the so-called the Interandean Depression, which was created at the end of lower Pliocene and where many thousands of meters of pyroclastics and sediments were deposited, mostly due to the erosion and high volcanic activity up to the present day (Winter and Lavenù, 1989; Tibaldi and Ferrari, 1992; Coltorti and Ollier, 2000). The El Trébol (traffic hub) sinkhole is situated within the thick sequence of sediments of the Interandean Depression, right next to the western flanks of the Pichincha volcanic complex (Monzier et al., 2002; Robin et al., 2008). These Quaternary deposits are composed of the (a) Cangahua Formation, (b) conglomerates, (c) alluvial sediments and (d) refilling of sediments and materials (Clapperton and Vera, 1986).

The Cangahua Formation is a $25-30 \mathrm{~m}$ thick sequence with usually a yellowish-brownish color that is composed

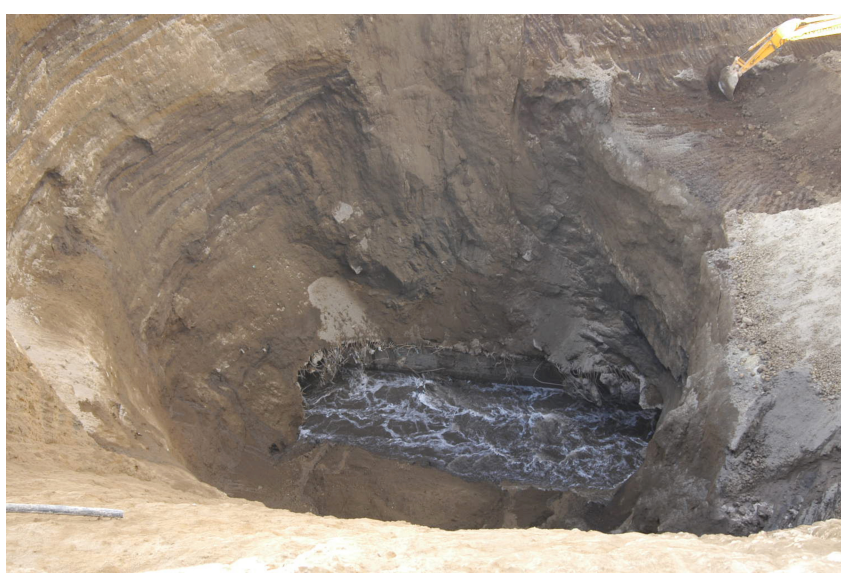

Figure 4. View into the sinkhole with the appearance of the Machángara River at its base.

of paleo-soils, fine-grained volcanic tuff, pumices, eolianreworked volcanic ash and glacial loess as well as occasional mudflows and alluvial channels (Hall and Mothes, 1997). Generally, the grain size distribution of the Cangahua Formation is silty to sandy, well consolidated, with low permeability and extremely stable when dry but collapsible in contact with water. The strength of these materials is highly reduced producing instability of slopes, which collapse in the form of blocks (O'Rourke and Crespo, 1988).

The conglomerates that outcrop in the vicinity of the sinkhole are composed of sub-rounded to rounded boulders and gravels, within a silty to sandy compacted matrix. Nonetheless, these deposits are absent in the stratigraphy of the sinkhole. In the lower part of the sequence are sub-rounded, up to meter-sized fluvial transported blocks, surrounded by smaller material of previous terraces. This deposit is very compact, presenting a high resistance to loosening.

In order to construct the transport exchanger designed for that site, the deviation of the Machángara River has been performed on a stretch of approximately $300 \mathrm{~m}$. Above this structure a silty-sand compacted filling was placed, corresponding to materials involved in the sinking. At the northeastern side of the compacted filling, a non-damaged area was observed, having a middle strength. These materials presented $N$ values between 17 and 28 obtained with a standard penetration test (SPT) drilling. No water phreatic level has been observed in this area. Nonetheless, at the southern and southwestern side of the slopes of the sinkhole, water flows have been observed at a depth of $20 \mathrm{~m}$, which will be discussed later on in this paper.

\section{Hydrological conditions}

The distribution of rainfall in the Trébol area along the year considering data from 1975 shows the prevalence of two periods with abundant rainfall, February-May and October- 
November, with 133 and $115 \mathrm{~mm}$ on average respectively, while the drier seasons correspond to June-September and December-January, with $42 \mathrm{~mm}$ on average (EMAAP-Q, 2006; INAMHI, 2010; Fig. 5). On the other hand, as for the multiannual distribution of rainfall, it is important to highlight that the wet season between January and March of 2008 was considered the strongest of the last 20 years with accumulated rainfall during the first three months of 2008 being much higher than the recorded during other heavy rainy seasons of 1989, 1993 and 2000 (Salazar et al., 2009). In particular, a peak of $21.2 \mathrm{~mm}$ was registered on 31 March 2008 during a heavy rainfall that lasted $4 \mathrm{~h}$ from 13:00 to 17:00 (INAMHI, 2008, 2010; Salazar et al., 2009). Additionally, within all of 2008 and coinciding in the three meteorological stations closest to El Trébol, March recorded continuous raining since it was the month with the highest number of days of rain, with 27 and 29 out of 31 days in Iñaquito and Izobamba respectively (Fig. 5a, b, c).

The hydrographic network of the south valley of Quito is classified as dendritic, having the Machángara as its main river course. The Machángara rises in the steep foothills of Atacazo volcano and crosses the valley from south-west to north-east running parallel to the basin until it reaches the Trébol area (Panecillo) where it takes a turn to the east, becomes deeper and flows to the valleys of Cumbayá and Tumbaco. Another important drainage is the so-called "Quebrada Grande", which has its source in the northwest foothills of Atacazo volcano and for a stretch it aligns parallel to the Machángara River until it becomes its tributary. When it exits to the valley, the Machángara River flow varies between $3 \mathrm{~m}^{3} \mathrm{~s}^{-1}$ during dry season and $170 \mathrm{~m}^{3} \mathrm{~s}^{-1}$ during the wet season. Furthermore, the Machángara River is the main sewage receiver of Quito.

\section{Hydrogeology of the study area}

After sinking and collapse took place, groundwater emerged in the south and southwestern slopes at a depth of $20 \mathrm{~m}$ from the upper rim of the slope (Fig. 6), These water springs contributed with a total flow of around $6 \mathrm{~m}^{3} \mathrm{~s}^{-1}$, which decreased $50 \%$ due to drilling of pumping wells strategically located. These springs revealed the presence of a free aquifer located at the south side of the sinkhole. Indeed, the existence of the aquifer was determined after field observations followed by three drillings; the water table is located between 12 and $15 \mathrm{~m}$ deep. The aquifer is composed of granular materials within a silty-sandy matrix, with a thickness of around $18 \mathrm{~m}$ with a gradient from southwest to northeast, toward the Machángara River (Fig. 7). The aquifer recharge probably takes place in the Luluncoto gorge situated $2 \mathrm{~km}$ to the southwest.

A flow of around $10 \mathrm{~m}^{3} \mathrm{~s}^{-1}$ was obtained from the aquifer considering two sources: (1) the continuous pumping from the wells and (2) the water springs from the south slope of

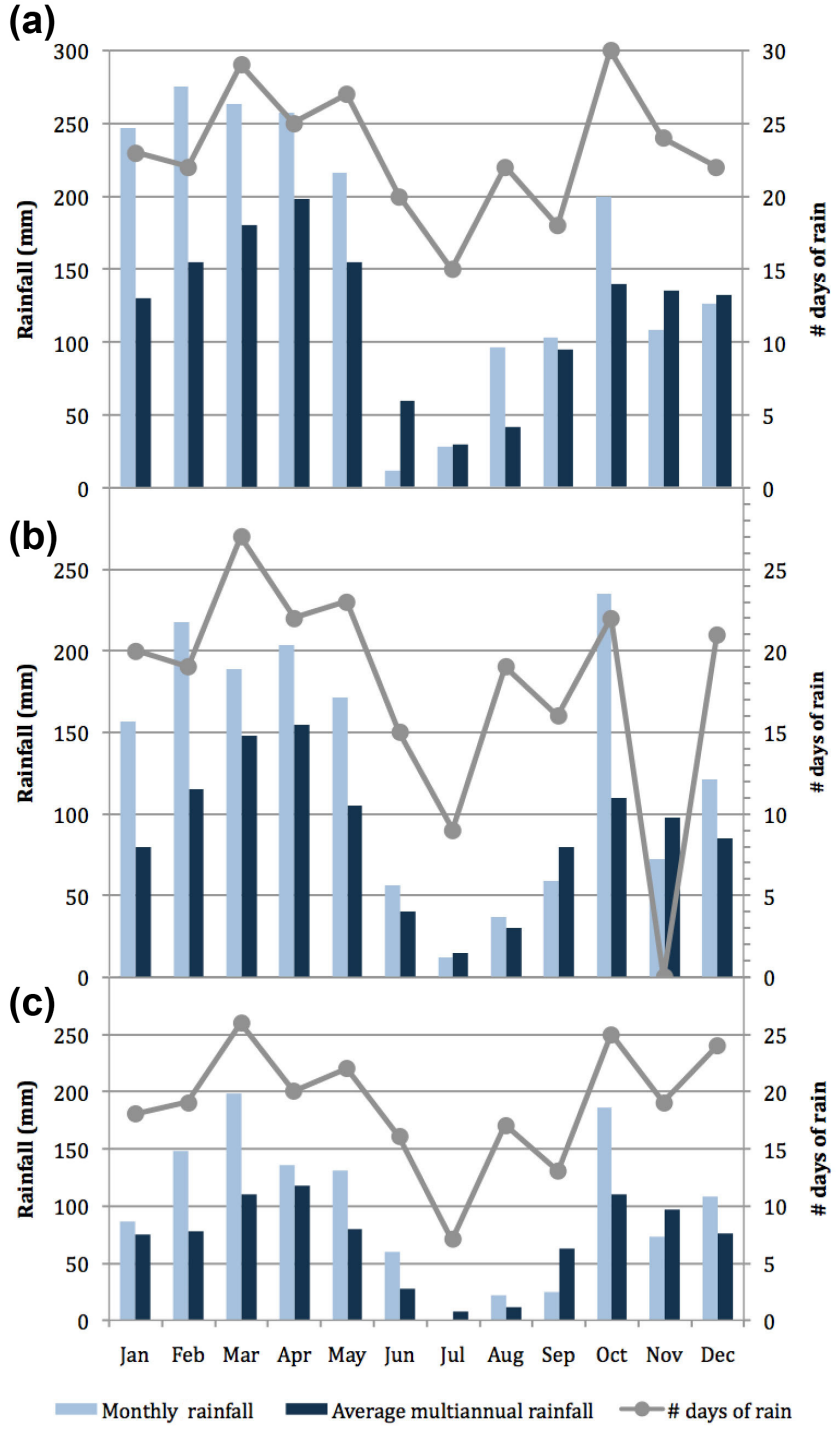

Figure 5. Total monthly rainfall, average multiannual rainfall (data since 1975) and number of days with rain per month (higher than $0.1 \mathrm{~mm}$ ) of the three meteorological stations closest to El Trébol (a) Izobamba: latitude: -0.366089 , longitude: -78.555061 ; altitude: $3085.00 \mathrm{~m}$ a.s.1.; (b) Iñaquito: latitude: -0.175000 ; longitude: -78.485278; altitude: 2789.12; (c) La Tola: latitude: -0.231667 ; longitude: -78.370333 , altitude: $2480 \mathrm{~m}$ a.s.1. From INAHMI (2010).

the sinkhole. Despite this $10 \mathrm{~m}^{3} \mathrm{~s}^{-1}$ flow that was permanently extracted, the aquifer kept on flowing, suggesting that its recharge must have been higher than $10 \mathrm{~m}^{3} \mathrm{~s}^{-1}$. Therefore, this flow should be taken into account when performing any reconstruction work in the area (Table 1). 


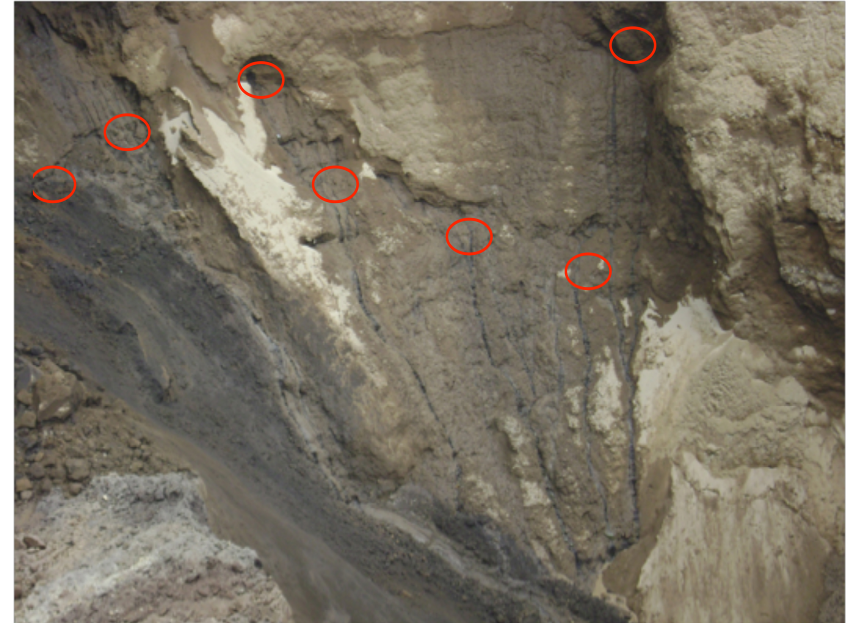

Figure 6. Southern and southwestern side of the inner part of the sinkhole, where water flows.

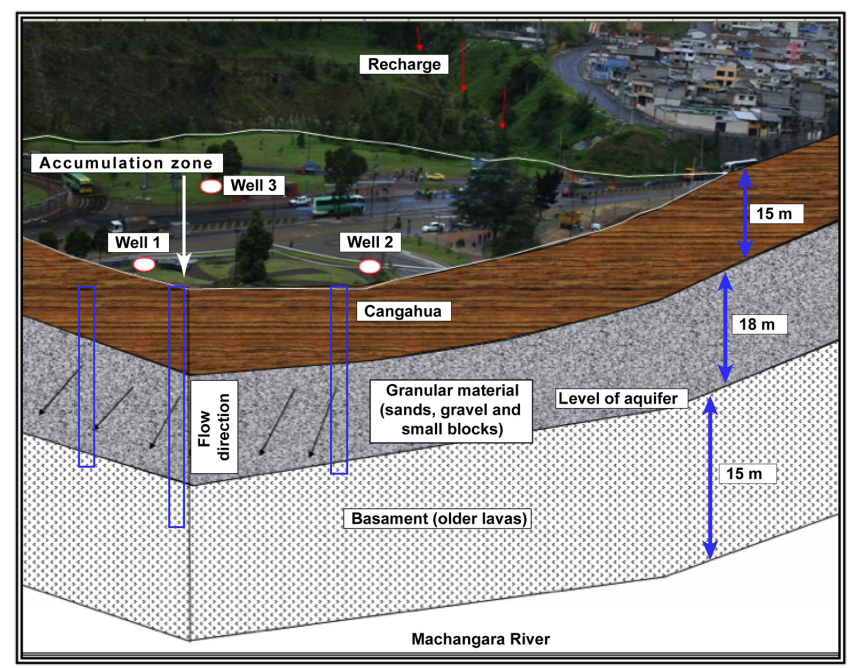

Figure 7. Conceptual model of the aquifer with the site of the wells and the flowing direction.

\section{Historical hydraulic facilities of the area}

The site where El Trébol was constructed is about 300$600 \mathrm{~m}$ downstream of the confluence of Jerusalem and El Tejar streams with the Machángara River. Today, the channeled stream of Jerusalem is 24 de Mayo Avenue and its extension to the old bus station, currently Qumandá Park. The channeled stream of El Tejar, after passing below the historic center, merges and flows with the stream of Manosalvas down in the low neighborhood of San Juan, in the area that is the center's transit transfer, now known as La Marin, before reaching Machángara River.

As a result of uncontrolled growth of the city, this natural drainage system was conducted on sewer channels below the construction of roads for vehicular traffic. Historical records

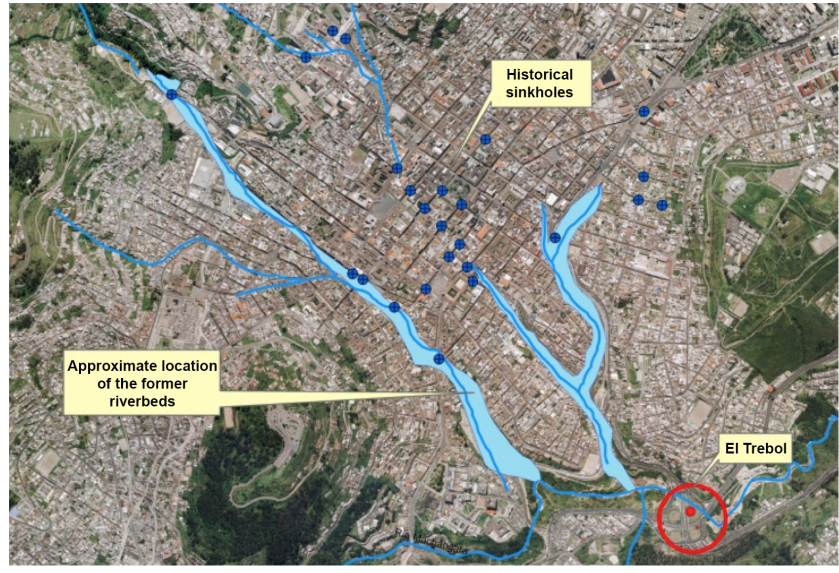

Figure 8. Historical sinkholes in the form of subsidence (blue circles) at Machángara River, including the El Trébol sector (marked with the red circle and red dot).

include 12 sinkholes (Table 2; Fig. 8) of different magnitudes, defined as "declines or collapses of roadway in the filler material streams, caused by faulty sewers", as well as the filling, initially performed with debris and garbage, the age, type of construction and degree of deterioration of the physical work of the channels, sewers and collectors (Peltre, 1989). These former sinkholes are undoubtedly aligned along the earlier and now covered river channels on the old bed of the filled streams. Therefore, we can assume that they will continue to occur, especially in periods of daily rainfall above the historical average. In the area of El Trébol, the first serious collapse was registered 31 March 2008, 10 years after channels were made for the construction of the infrastructure to solve the problems of the traffic jams. Furthermore, there was a second sinkhole in almost the same spot but of less extension compared to the one in 2008 on 10 January 2014 (Fig. 9).

\section{Analysis of the causes of the sinkhole}

The sinkhole generated in El Trébol site involved $25000 \mathrm{~m}^{3}$ of displaced earthy material. It started in the form of a crater with a diameter of approximately $30 \mathrm{~m}$, amplifying its size constantly due to the instability of the slopes, especially since more water has been involved from the high precipitation. Further presence of groundwater has been noticed in the southern slope of the sinkhole, when it reached some $120 \mathrm{~m}$ in diameter and $40 \mathrm{~m}$ in depth, determined from the top part down to the previously covered river. That river was detected after the visible collapse of the squeezed river concrete channel of the Machángara River for a distance of some $20 \mathrm{~m}$.

Three hypotheses were taken into consideration as the most probable cause for this disaster: (a) extreme water discharge, (b) erosive process that affect the structure of col- 
Table 1. Characteristics of wells and slopes.

\begin{tabular}{|c|c|c|c|c|c|c|}
\hline Description & $\begin{array}{r}\text { Depth } \\
(\mathrm{m})\end{array}$ & $\begin{array}{r}\text { Diameter } \\
(\mathrm{cm})\end{array}$ & $\begin{array}{r}\text { Depth of phreatic } \\
\text { level (m) }\end{array}$ & $\begin{array}{r}\text { Depth of static } \\
\text { level }(\mathrm{m})\end{array}$ & $\begin{array}{r}\text { Depth of } \\
\text { pumping }(\mathrm{m})\end{array}$ & Volume $\mathrm{m}^{3} \mathrm{~s}^{-1}$ \\
\hline Well 1 & 32 & 20 & 12 & 20 & 25 & 1.2 \\
\hline Well 2 & 37 & 20 & 15 & 22 & 24 & 2.0 \\
\hline Well 3 & 38 & 20 & 15 & 23 & 27 & 4.0 \\
\hline \multirow[t]{2}{*}{ Slopes } & 20 & & - & - & - & 3.0 \\
\hline & & & & & Total & 10.2 \\
\hline
\end{tabular}

Table 2. Historical register of sinkholes and collapses.

\begin{tabular}{rll}
\hline Event & Streets (on top of former streams) where sinkholes occurred & Associated former stream \\
\hline 29 May 1907 & Morales (La Ronda), Benalcázar y García Moreno & Jerusalem \\
09 May 1909 & Benalcázar, Espejo & Manosalvas/La Marín \\
2 Mar 1910 & Benalcázar, Sucre & El Tejar \\
10 Apr 1911 & Avenida 24 de Mayo & Jerusalem \\
7 Jan 1919 & Pereira al norte de Santo Domingo & Manosalvas/La Marín \\
6 Mar 1920 & Flores (Manosalvas), Sucre & Manosalvas/La Marín \\
24 Feb 1921 & Del Correo (Venezuela), Espejo & Manosalvas/La Marín \\
6 Oct 1922 & Guayaquil, Manosalvas & Manosalvas/La Marín \\
6 Oct 1922 & Mideros & Manosalvas/La Marín \\
14 Dec 1922 & Morales (La Ronda), García Moreno & Jerusalem \\
10 Jan 1928 & Venezuela & Manosalvas/La Marín \\
21 Mar 1928 & Guayaquil, Sucre, Bolívar & Manosalvas/La Marín \\
25 Apr 1950 & Rocafuerte, Guayaquil & Manosalvas/La Marín \\
24 Jan 1983 & Paredes, Morales (La Ronda) & Jerusalem \\
29 Jan 1983 & García Moreno, Venezuela, Guayaquil & Manosalvas La Cava \\
\hline
\end{tabular}

lapsible materials and chemical alteration through time, and finally (c) influence of groundwater.

\subsection{Extreme water discharge}

One of the most likely triggers may be the high amount of flowing and floating material that was carried by the river. A strong rainfall with $21 \mathrm{~L} \mathrm{~m}^{-2}$ appears to have damaged the weakest area of the vault, located $145 \mathrm{~m}$ from the gate of the Machángara River. Materials found $2 \mathrm{~m}$ upstream the highest tunnel entrance point may indicate that the water flow had a high load capacity to transport these materials because the channel was over-pressured. The detachment of the concrete cover of the vault of the channeled part of the tunnel produced a drag filler, which formed in a few hours a conduct of about $30 \mathrm{~m}$ in diameter at the surface, which later even became extended.

\subsection{Erosive processes and chemical alteration with time}

As previously described, the Machángara River has a variable behavior in time. Typical significant decreases in dry seasons reached a minimum of $3 \mathrm{~m}^{3} \mathrm{~s}^{-1}$, while sharp increases in wet season generated floods up to $170 \mathrm{~m}^{3} \mathrm{~s}^{-1}$. These variations have been the main cause for the deteri- oration of the structural elements of the channel (iron and concrete) and will be described below.

\subsubsection{Potential damage of structures by the river in dry season}

Considering that the Machángara River is the largest recipient of discharges of sewage and industrial effluents from the city of Quito and water consumption in the city is about $7 \mathrm{~m}^{3} \mathrm{~s}^{-1}$ and $40 \%$ of this flow $\left(2.8 \mathrm{~m}^{3} \mathrm{~s}^{-1}\right)$ is a product of the southern part of Quito, then we suppose that in dry seasons the flow through the Machángara River corresponds to sewage and industrial effluents that are produced in the south of the city (Arias Jiménez, 2008). Furthermore, at drier times the potential of chemically altered waters may additionally influence structures by corrosion and may cause systematic deterioration of the elements and the weakening of the structures as a whole. Nonetheless, as the waters flowing though the Machángara River are sometimes altered and change even their chemistry, being sometimes even slightly basic, this aspect may be disregarded. 


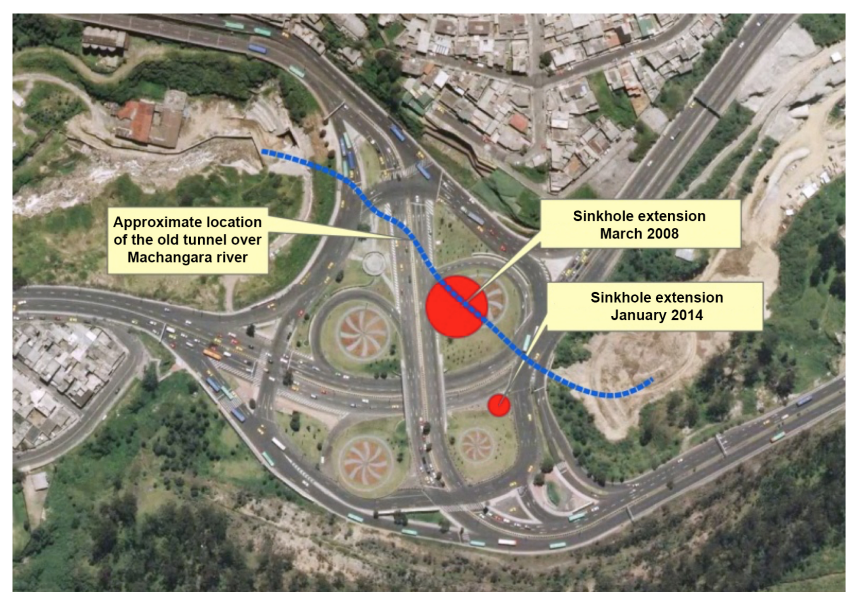

Figure 9. El Trébol sector with the flowing direction of the Machángara River including the sinkholes of 31 March 2008 (big red circle) and the recent but smaller one of 10 January 2014 (small red circle).

\subsubsection{Potential damage of structures by crescents of the river}

In wintertime the river has high flow rates, reaching up to $170 \mathrm{~m}^{3} \mathrm{~s}^{-1}$. There is sufficient capacity to both receive sewage and cause a dilution of the elements, changing hereby dramatically the water chemistry (reduction of the conductivity, $\mathrm{pH}$, etc.), becoming a less aggressive water (Arias Jiménez, 2008).

The water with the chemical conditions described above does not cause a significant effect on the elements of the collector at all. The potential alteration is rather directly related to the high speeds of the water and sediment carried by the river (large boulders, scrap wood, etc.), which collide with the structures producing weakening, fracturing and erosion, mainly at the floor (see Fig. 10a) (Arias Jiménez, 2008).

Based on the analysis of the behavior of the river in dry and wet seasons, we may assume that the collapse of the channel was caused by a systematic alteration of structural elements and by the loosening of structure and erosion produced within a thick sequence of sediments and to a much less extent by the chemical action of the waters.

This hypothesis is based on the fact that, in the collapsed collector on the left margin of the channel, there are no vestiges of the floor. This is possible because the channel turns and the water collides in the union of the right gable with the floor, causing weakening and faulting. The water caused localized erosion leaving the right transept without support and initiated a process of dragging of sediments filling and covering the channel, causing the phenomenon known as piping, a process that is accelerated due to the presence of underground stream water (Arias Jiménez, 2008), as illustrated in Fig. 10a-c.

As a result of piping, a cavern formed and the material of the collapse was transported downstream. The soil lost sus- tainability and collapse of the filling occurred, leading to the formation of the sinkhole in the form of a crater. As stated above at first the sinkhole had a diameter of 30 to $40 \mathrm{~m}$, while a little later due to the constant landslides caused by the action of rain and the presence of groundwater, it finally reached a diameter of 120 to $140 \mathrm{~m}$.

\subsection{Influence of the groundwater}

A last hypothesis to be considered is the potential influence of groundwater, directly related to the construction process. For the construction of the channel and subsequent filling thereof, the designs did not consider a drainage system for groundwater that surfaces in the south slope, to avoid saturation of the filling material and to control the pore pressure, which may reach very high values. There are many examples where pore pressure is associated with the fracture of walls in hydraulic works such as dams, tunnels, reservoirs, viaducts, etc. (Arias Jiménez, 2008).

\section{Direct and indirect financial damage}

The sinkhole in the traffic interchange known as El Trébol was the consequence of previous downpour rain. According to Salazar et al. (2009) January, February and March of 2008 experienced record rainfall. Just the day before the sinkhole creation, rain fell with an intensity of $21.2 \mathrm{~mm}$. All this heavy rain triggered an enormous pressure on the old drainage system, which caused Machángara River drainage vault to collapse.

The day after the sinkhole, the Ecuadorean government created a line of credit of USD 60 million to help the city and start the reconstruction (La Hora, 2008). On the same day, Quito's mayor and the city council created an emergency fund of USD 200000 . This emergency fund was later increased to about 1 million. The day after the drainage vault collapsed, the rebuilding process started with a team of 5 hydraulic excavators, 5 power shovels, 10 roll-off trucks and 4 systems of mobile industrial lighting. In the rebuilding process 210 teams of workers were at the site 24/7 (El Universo, 2008). The reconstruction of the cloverleaf interchange took 8 months before full traffic recovery, yet the entire reconstruction of the site took 22 months (El Universo, 2008). El Trébol total reconstruction cost reached over USD 13 million (Table 3).

However, this overall cost does not reflect the real cost of the damage that occurred by the sinkhole development, as it does not take into account all indirect costs associated with this event. A further, additional cost which has not been taken into account is defined as uncompensated effects that affect user utility or well-being - the social cost (Cowen, 1992), meaning how users were affected by the sinkhole and cloverleaf interchange reconstruction. For instance, local authorities closed schools during the first week after the event. 

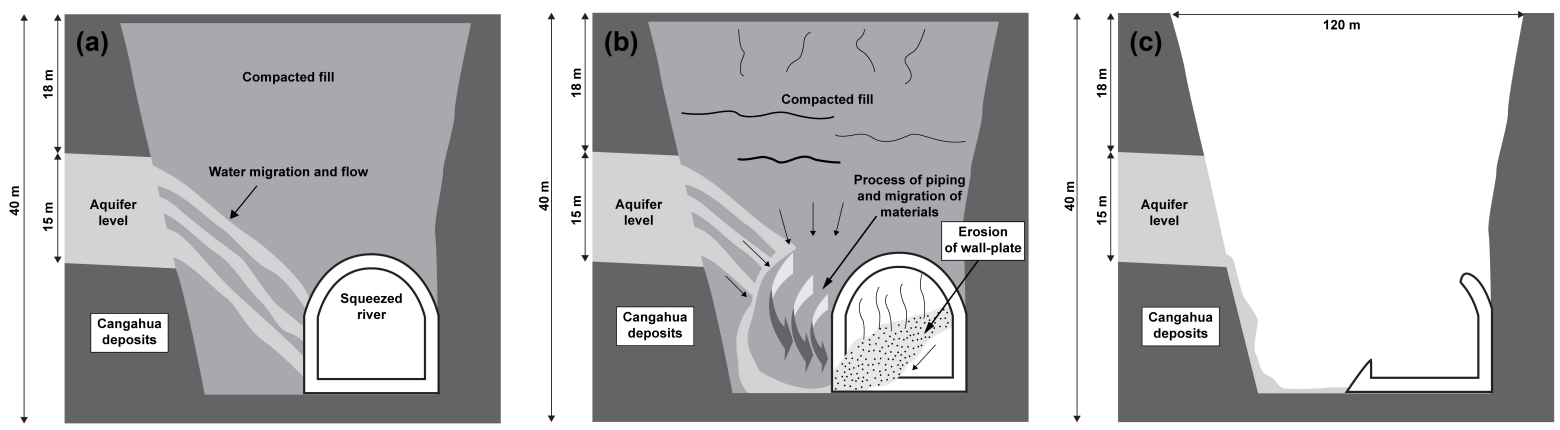

Figure 10. (a) Schematic view of the channelized river, the characteristics of the terrain and of the compacted fill; (b) alteration of the compacted fill, process of piping and migration of materials, initial stage of the collapse; (c) formation of sinkhole, material drags surroundings due to river activity.

Table 3. List of the costs of the reconstruction in USD. Data from MDMQ (2005).

\begin{tabular}{lr}
\hline New tunnel & 7575872.21 \\
Rental of equipment & 352622.93 \\
Land movement & 151526.15 \\
Labor & 801546.35 \\
Construction materials & 435495.03 \\
Services & 219061.16 \\
Other costs & 31236.78 \\
EMOP (Metropolitan Company of & 2000000.00 \\
Public Construction) & \\
Vida Para Quito & 2000000.00 \\
\hline Total & 13567360.61 \\
\hline
\end{tabular}

Hereby, the cost of students losing classes are not included, nor are the costs as a result of the losses of the teachers' income, who usually earn an hourly wage.

We analyzed indirect costs of users who were affected but were not compensated for. Because of lack of official information, we concentrated our efforts on estimating the cost of losing time during the reconstruction of the cloverleaf interchange and drainage vault, as well as the additional cost in gasoline burning by users while they were stuck in traffic of this crucial cloverleaf interchange.

In case of additional cost in gasoline, 80000 vehicles circulate and use El Trébol every day, in addition to 400 interparish public transportation buses (La Hora, 2008). In order to estimate the value lost by a user, we concentrated on private transportation under the assumption that car owners who use their car to go to their job and back home fill their gas tanks once a week. This assumption seems reasonable for most car owners. An average of $50.75 \mathrm{~L} / 100 \mathrm{~km}$ was reported for a middle-size car in Quito (López, 2013) Yet, we did not include public transportation because we did not know how many times the gas tanks are filled in a week. Based on public estimations, we used a value of USD 0.02 as an additional cost that owners have to pay to fill their gas tank. It is reason-
Table 4. Vehicle type and different gasoline prices in USD.

\begin{tabular}{lrr}
\hline Vehicle & \multicolumn{2}{c}{ Gasoline price } \\
type by gasoline use & USD/gallon & Total cost* \\
\hline 17456 "super premium" & 2.00 & 11210941.44 \\
62544 "extra" & 1.48 & 40168258.56 \\
\hline Total gasoline & & 51379200.00 \\
\hline * adding USD 0.07 & & \\
\hline
\end{tabular}

Table 5. Cost category expressed in delays of 25 and $35 \mathrm{~min}$.

\begin{tabular}{lrr}
\hline Cost category & $25 \mathrm{~min}$ & $35 \mathrm{~min}$ \\
\hline CPVTOTAL & 34185200.00 & 47859280.00 \\
CPSTOTAL & 15668216.67 & 21935503.33 \\
CPAvVITOTAL & 7121916.67 & 9970683.333 \\
CPúTOTAL & 11395066.67 & 15953093.33 \\
\hline Total cost & 68370400.00 & 95718560.00 \\
\hline $\begin{array}{l}\text { cost of private owners from Chillos Valley - CPVTOTAL; cost to } \\
\text { private owners from south of Quito - CPSTOTAL; cost to private } \\
\text { owners driving to south of Quito - CPAvVITOTAL), (cost of users of } \\
\text { public transportation - CPúTOTAL }\end{array}$
\end{tabular}

able also to assume that car owners spend USD 20 per week filling their gas tanks. USD 0.02 seems to be a low bound, but it is still reasonable. Then, we multiply the value of $1 \mathrm{~L}$ of gasoline adding USD 0.02 .

Based on AIHE statistics (AIHE, 2015), we know that $21 \%$ of car owners used a "super premium" gasoline, which has a price of USD 0.53 per liter and $78 \%$ used "extra" gasoline with a price of USD 0.39 per liter. Based on the number of vehicles which circulated at that time El Trébol every day, 80000 cars per day, we can say that approximately 17000 cars used "super premium" gasoline and over 62000 used "extra" gasoline type (Table 4). We estimated that additional cost in gasoline for private car owners was USD 85 million for those 8 months of traffic problems at El Trébol. 
Table 6. Cost category.

\begin{tabular}{|c|c|c|}
\hline $\begin{array}{l}\text { Cost } \\
\text { category }\end{array}$ & $\begin{array}{l}\text { Amount } \\
\text { USD }\end{array}$ & $\begin{array}{l}\text { Reconstruction / } \\
\text { indirect cost ratio }\end{array}$ \\
\hline Reconstruction cost & 13567360.61 & \\
\hline Additional gasoline cost & 51379200.00 & 0.264 \\
\hline Opportunity cost $25 \mathrm{~min}$ & 68370400.00 & 0.198 \\
\hline Opportunity cost $35 \mathrm{~min}$ & 95718560.00 & 0.142 \\
\hline
\end{tabular}

We did not include car depreciation value. Even now, it is well known that keeping a car running while waiting depreciates its value faster than normal conditions. We included neither public transportation nor car owners who own a diesel engine car.

Concerning the cost of time lost (an opportunity cost), we estimate its value from per hour salary multiplied by the additional time that users had to spend during the reconstruction process. We assumed that users lost between 25 up to 35 min during their travel to workplaces and going back to their homes. Users lost between USD 2.23 up to 3.12 per hour. This value is multiplied by the total time lost during site reconstruction. Since users came from different directions, we estimate the loss value separately. According to media reports, at that time 80000 private vehicles circulated throughout El Trébol per day: 48000 came from Los Chillos Valley (cost of private owners from Chillos Valley - CPVTOTAL, 22000 from the southern part of Quito (cost to private owners from south of Quito - CPSTOTAL), 10000 from toward the valley or the southern part of the city (cost to private owners driving to south of Quito - CPAvVITOTAL), and 400 units of public transportation (cost of users of public transportation CPúTOTAL). Regarding public transportation, we assumed that each unit was carrying 40 passengers each trip, which it is a low bound because during rush hour these units can be at full capacity (around 72 passengers).

Finally we estimate users' opportunity cost by multiplying per hour lost times by the time of El Trébol reconstruction, which was 8 months. The users' opportunity cost for each category is presented in Table 5.

Users lost a considerable amount of time when reconstruction took place. Adding all users (the aggregate value) it turned out that the real cost of the sinkhole increases significantly. As Table 5 shows, under the assumption that users lost only $25 \mathrm{~min}$, the opportunity cost reaches over USD 68 million during the 8 months of reconstruction; under the assumption that a user lost up to $35 \mathrm{~min}$, the opportunity cost reaches over 95 million. As a result, the real cost (under $25 \mathrm{~min}$ assumption) leads to USD 133316960.61 , while a 35 min assumption leads to USD 160665120.61 as the real cost.

The ratio between reconstruction cost and the other cost presents that reconstruction cost is only a low percent of real cost, as Table 6 shows; the ratio between reconstruction cost and additional gasoline cost is only 0.26 , meaning that reconstruction cost is only about $26 \%$ of real cost, only $19.8 \%$ of opportunity cost for $25 \mathrm{~min}$, and $14.2 \%$ for $35 \mathrm{~min}$.

\section{Conclusions}

As the main conclusion of this event, after the analysis of economic losses we consider it a priority to carry out corresponding actions to prevent future collapses. Taking into consideration the alignment of the current and past sinkholes, the zones in which the alignments appear need to be reinforced in order to avoid future disasters. Besides the potential risk of lives lost, as demonstrated in our study, the indirect costs caused by the studied sinkhole were much higher than those due to the reconstruction of the disaster site itself. Unfortunately, the enforcement of the potential sinking areas has not taken place yet, as demonstrated by a new sinkhole in 2014 in a zone where the vulnerability has been previously emphasized. To prevent future collapses, from a riskmanagement approach we suggest the following: (1) a detailed study about hydrological and hydrogeological characteristics of urban and industrial areas; (2) determination of the silty-sandy material susceptibility to collapse by detailed geotechnical characterization, (3) an action plan to act on areas identified as potentially vulnerable with monitoring and mitigation measures; and (4) the development of future sustainable urban and industrial projects considering a hydrogeological approach.

Acknowledgements. We thank the Universidad de las Fuerzas Armadas ESPE for logistic and financial support. We also acknowledge the Facebook Group "All scary sinkholes in one place" for the inspiration to publish this article. Fernando Mato acknowledges support from the Prometeo Project of the National Secretariat of Higher Education, Science, Technology and Innovation (SENESCYT), Ecuador.

Edited by: S. Fuchs

Reviewed by: L. Jordá-Bordehore and one anonymous referee

\section{References}

AIHE: Estadísticas, Asociación de la Industria Hidrocarburífera del Ecuador, Quito, available at: http://www.aihe org.ec/index.php?option=com_content \&view=article \&id=122: estadisticas\&catid=67\&Itemid=142 (last access: 2016), 2015.

Aisong, D. and Jianhua, J.: Land subsidence, sinkhole collapse and earth fissure occurrence and control in China, Hydrol. Sci. J., 39, 245-256, 1994.

Arias Jiménez, N. E.: Hundimiento El Trebol "Respuesta a la emergencia”, Unpublished Thesis, Instituto de Altos Estudios Nacionales, Quito, Ecuador, 52 pp., 2008.

Beck, B. F.: On calculating the risk of sinkhole collapse, in: Appalachian Karst, Proceedings of the Appalachian Karst Symposium, 1991. 
Beck, B. F.: Soil piping and sinkhole failures, in: Enyclopedia of caves, edited by: White, W. B., Elsevier, New York, 523-528, 2004.

Brinkmann, R., Parise, M., and Dye, D.: Sinkhole distribution in a rapidly developing urban environment: Hillsborough County, Tampa Bay area, Florida, Eng. Geol., 99, 169-184, 2008.

Bruno, E., Calcaterra, D., and Parise, M.: Development and morphometry of sinkholes in coastal plains of Apulia, southern Italy, Preliminary sinkhole susceptibility assessment, Eng. Geol., 99, 198-209, 2008.

Clapperton, C. M. and Vera, R.: The Quaternary glacial sequence in Ecuador: a reinterpretation of the work of Walter Sauer, J. Quaternary Sci., 1, 45-56, 1986.

Coltorti, M. and Ollier, C. D.: Geomorphic and tectonic evolution of the Ecuadorian Andes, Geomorphology, 32, 1-19, 2000.

Cowen, T. (Ed.): Public Goods and Market Failures, New Brunswick, N.J., Transaction Publishers, 1992.

Dougherty, P. H. and Perlow Jr., M.: The Macungie Sinkhole, Lehigh valley Pennsylvania: Cause and repair, Environ. Geol. Water S., 12, 89-98, 1988.

El Universo: Se buscan vías alternas por hundimiento en sector El Trebol de Quito, available at: http://www.eluniverso.com/2008/ 04/01/0001/12/555F7445DA114F59A5A7C7D8C0564C44. html, last access: 1 April 2008.

EMAAP-Q: Estudio Hidrogeológico del acuífero del Valle de los Chillos", Quito, Ecuador, 112 pp., 2006.

Gutiérrez, F., Galve, J. P., Guerrero, J., Lucha, P., Cendrero, A., Remondo, J., Bonachea, J., Gutiérrez, M., and Sánchez, J. A.: The origin, typology, spatial distribution and detrimental effects of the sinkholes developed in the alluvial evaporite karst of the Ebro River valley downstream of Zaragoza city (NE Spain), Earth Surf. Proc. Landf., 32, 912-928, 2007.

Gutiérrez, F., Cooper, A. H., and Johnson, K. S.: Identification, prediction, and mitigation of sinkhole hazards in evaporite karst areas, Environ. Geol., 53, 1007-1022, 2008.

Gutiérrez, F., Galve, J. P., Lucha, P., Bonachea, J., Jordá, L., and Jordá, R.: Investigation of a large collapse sinkhole affecting a multi-storey building by means of geophysics and the trenching technique (Zaragoza city, NE Spain), Environ. Geol., 58, 11071122, 2009.

Gutiérrez-Santolalla, F., Gutiérrez-Elorza, M., Marín, C., Desir, G., and Maldonado, C.: Spatial distribution, morphometry and activity of La Puebla de Alfindén sinkhole field in the Ebro river valley (NE Spain): applied aspects for hazard zonation, Environ. Geol., 48, 360-369, 2005.

Hall, M. and Mothes, P.: El origen y edad de la Cangahua superior, valle de Tumbaco, Ecuador, in: Suelos volcánicos endurecidos, edited by: Zebrowski, C., Quantin, P., and Trujillo, G., Mem III Symp Intern ORSTOM, Quito, 19-28, 1997.

Hermosilla, R. G.: The Guatemala City sinkhole collapses, Carbonate. Evaporite., 27, 103-107, 2012.

INAHMI (National Institute of Meteorology and Hydrology): Meteorological yearbook, Nr. 48, Quito, Ecuador, 123 pp., 2008.

INAHMI (National Institute of Meteorology and Hydrology): Meteorological yearbook, Nr. 50, Quito, Ecuador, 139 pp., 2010.

Kaufmann, G. and Romanov, D.: Geophysical investigation of a sinkhole in the northern Harz foreland (North Germany), Environ. Geol., 58, 401-405, 2009.
Krawczyk, C. M., Polom, U., Trabs, S., and Dahm, T.: Sinkholes in the city of Hamburg - New urban shear-wave reflection seismic system enables high-resolution imaging of subrosion structures, J. Appl. Geophys., 78, 133-143, 2012.

La Hora: El Trebol se cayó en Quito, available at: http://www. lahora.com.ec/index.php/noticias/show/703827/-1/El_Tr\%C3\% A9bol_se_cay\%C3\%B3_en_Quito.html\#.VT4-MtJ_NHw, last access: 6 April 2008.

Lei, M. T., Li, Y., Jiang, X. Z., Gan, F. P., and Meug, Y.: Preliminary study on the technology and method of sinkhole collapse monitoring and prediction: As an example of sinkhole collapse monitoring station in Zhemu Village, Guilin City, The Chinese Journal of Geological Hazard and Control, 15, 142-147, 2004.

López, J. L.: Evaluación del consumo de combustible de vehículos livianos en el Distrito Metropolitano de Quito, Tesis previa a la obtención del Grado de Magister (MSc) en Sistemas Automotrices, Escuela Politécnica Nacional, Quito, Ecuador, 170 pp., 2013.

Margiotta, S., Negri, S., Parise, M., and Valloni, R.: Mapping the susceptibility to sinkholes in coastal areas, based on stratigraphy, geomorphology and geophysics, Nat. Hazards, 62, 657-676, 2012.

MDMQ (Municipio del Distrito Metropolitano de Quito): Balance de los Estudios Urbanos (1985-2005) de la Coperación IRDMunicpio de Quito, in: Movilidad, elementos esenciales y riesgos en el Distrito Metropolitano de Quito, edited by: Demoraes, F., Co-edición MDMQ-IFEA-IRD, Quito, 218 pp., 2005

Monzier, M., Samaniego, P., Robin, C., Beate, B., Cotton, J., Hall, M. L., Mothes, P., Andrade, D., Bourdon, E., Eissen, J. P., Le Pennec, J. L., Ruiz, A. G., and Toulkeridis, T.: Evolution of the Pichincha volcanic complex (Ecuador), Proceedings of fifth international symposium on Andean geodynamics, Toulouse, 429 432, 2002.

Orndorff, R. C. and Lagueux, K. M.: Using geographic information systems (GIS) to determine geologic controls on the distribution of sinkholes in the Ozarks of south-central Missouri, in: Abstracts with Programs-Geological Society of America, 32, 3, p. $38,2000$.

O'Rourke, T. D. and Crespo, E.: Geotechnical properties of cemented volcanic soil, J. Geotech. Eng., 114, 1126-1147, 1988.

Paine, J. G., Collins, E. W., Wilson, C. R., Buckley, S., and John, A.: Preliminary investigations of subsidence, collapse, and potential for continued growth of the Daisetta Sinkhole, Liberty County, Texas, USA, 17 pp., 2009.

Peltre, P.: Quebradas y riesgos naturales en Quito, in: Riesgos Naturales en Quito, edited by: Peltre, P., Corporación Editora Nacional, Quito, Ecuador, 45-89, 1989.

Reese, A. J., Cantrell, A., and Scarborough, J.: Sinkhole and drainage planning in Johnson City, Tennessee, The Engineering Geology and Hydrogeology of Karst Terranes, 265-271, 1997.

Robin, C., Samaniego, P., Le Pennec, J. L., Mothes, P., and van der Plitch J.: Radiocarbon dating of Late Holocene phases of dome growth and Plinian activity at Guagua Pichincha volcano (Ecuador), J. Volcanol. Geotherm. Res., 176, 7-15, 2008.

Salazar, D., Demoraes, F., Bermúdez, N., and Zavgorodniaya, S.: De Trebol a girasol: consecuencias de un hundimiento ocurrido el 31 de marzo de 2008 en un eje esencial de la red vial de la ciudad de Quito, Bulletin de l'Institut français d'études andines, 38, 561-572, 2009. 
Salvati, R. and Sasowsky, I. R.: Development of collapse sinkholes in areas of groundwater discharge, J. Hydrol., 264, 1-11, 2002.

Shaqour, F.: Hydrogeologic role in sinkhole development in the desert of Kuwait, Environ. Geol., 23, 201-208, 1994.

Tibaldi, A. and Ferrari, L.: Latest Pleistocene-Holocene tectonics of the Ecuadorian Andes, Tectonophysics, 205, 109-125, 1992.

Waltham, T., Bell, F., and Culshaw, M.: Sinkholes and Subsidence, Springer, Chichester, 2005.
Williams, P.: Dolines, in: Encyclopedia of Caves and Karst Science, edited by: Gunn, J., Fitzroy Dearborn, New York, 304-310, 2003.

Winter, Th. and Lavenù, A.: Morphological and microtectonic evidence for a major active right-lateral strike-slip fault across central Ecuador South America, Ann. Tecton., 3, 123-139, 1989. 